\title{
Novel approaches in the high-risk prostate cancer patient: Summary of key research presented at AUA 2014
}

Cite as: Can Urol Assoc J 2014;8(7-8):S137. http://dx.doi.org/10.5489/cuaj.2285

Published online August 11, 2014.

\section{Abstract}

Another topic of focus at AUA 2014 was the subgroup of prostate cancer patients deemed to be at high risk.

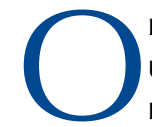
ne of the key concepts explored in this regard was the use of neoadjuvant therapy; this was the focus of a review session presented by Dr. Bruce Montgomery at AUA 2014. ${ }^{1}$ The use of neoadjuvant therapy has been proposed as a possible means of optimizing local control and treating micrometastatic disease prior to surgery. In other malignancies (e.g., breast and colorectal cancer), this is a well-established strategy that can improve survival. In prostate cancer, there is also some evidence of benefit for this strategy (e.g., the Radiation Therapy Oncology Group [RTOG] 8610 study including neoadjuvant androgen deprivation therapy [ADT] plus radiation); ${ }^{2}$ however, there have also been several studies in which neoadjuvant ADT did not significantly affect surgical failure rates compared to controls. ${ }^{3-6}$ A potential explanation for the failure of these ADT strategies to provide benefit in the trials in question is that standard ADT therapy does not have a substantial impact on tissue androgen levels. There is a need for other approaches to androgen deprivation in this setting, using novel agents and combinations. Several studies investigating such possibilities are ongoing; these include docetaxel + ADT; enzalutamide/abiraterone; enzalutamide/degarelix \pm trametinib or dasatinib; and enzalutamide \pm LHRH analogue.

In addition to the treatment of high-risk prostate cancer, there was also some interesting research presented regarding causes of death among high-risk patients. European researchers retrospectively investigated cause of death among 266 very-high-risk prostate cancer (cT3b/4) patients after radical prostatectomy across multi-institutional databases from 1998 to 2011. ${ }^{7}$ They reported that, even in this very-high-risk cohort, there was a
Table 1. Ten-year mortality rates for cancer-specific and other causes

\begin{tabular}{lcc}
\hline Age & $\begin{array}{c}\text { 10-year cancer-specific } \\
\text { mortality }\end{array}$ & $\begin{array}{c}\text { 10-year other-cause } \\
\text { mortality }\end{array}$ \\
\hline$<64$ years & $12.9 \%$ & $13.5 \%$ \\
$65-69$ years & $10.6 \%$ & $21.7 \%$ \\
$\geq 70$ years & $12.7 \%$ & $34.9 \%$ \\
$p$ value & 0.95 & 0.001 \\
\hline
\end{tabular}

substantial proportion of patients who died from causes other than cancer, and that this proportion increased with age. Tenyear mortality rates for cancer-specific and other causes are shown in Table 1.

\section{References}

1. Montgomery B. Neoadjuvant therapy for high risk prostate cancer. Presented at: The 2014 Annual Meeting of the American Urological Association; May 16-22, 2014; Orlando, FL.

2. Roach M 3rd, Bae K, Speight J, et al. Short-term neoadjuvant androgen deprivation therapy and external-beam radiotherapy for locally advanced prostate cancer: Long-term results of RTOG 8610. J Clin Oncol 2008;26:58591. http://dx.doi.org/10.1200/JC0.2007.13.9881

3. Aus $G$, Abrahamsson PA, Ahlgren $G$, et al. Hormonal treatment before radical prostatectomy: A 3-year followup. J Urol 1998;159:2013-6. http://dx.doi.org/10.1016/S0022-5347(01)63230-0

4. Klotz LH, Goldenberg SL, Jewett M, et al. CUOG randomized trial of neoadiuvant androgen ablation before radical prostatectomy: 36-month post-treatment PSA results. Canadian Urologic Oncology Group. Urology 1999;53:75763. http://dx.doi.org/10.1016/S0090-4295(98)00616-5

5. Schulman CC, Debruyne FMJ, Forster $G$, et al. 4-Year follow-up results of a European prospective randomized study on neoadjuvant hormonal therapy prior to radical prostatectomy in T2-3NOMO prostate cancer. European Study Group on neoadjuvant treatment of prostate cancer. Eur Urol 2000;38:706-13. http:// dx.doi.org/10.1159/000020366

6. Soloway MS, Pareek K, Sharifi R, et al. Neoadjuvant androgen ablation before radical prostatectomy in cT2bNxMo prostate cancer: 5-year results. J Urol 2002;167:112-6. http://dx.doi.org/10.1016/S00225347(05)65393-1

7. Moltzahn F, Karnes JA, Gontero P, et al. Predicting prostate cancer specific outcome after radical prostatectomy among men with cT3b/4 PCa with or without additional high risk factors: A multi-institutional outcome study Of 266 patients. Abstract presented at: The 2014 Annual Meeting of the American Urological Association; May 16-22, 2014; Orlando, FL. Abstract MP45-04.

Correspondence: Dr. Neil Fleshner, 610 University Ave., Suite 3-130, Toronto ON M5G 2M9; neil.fleshner@uhn.on.ca 